\title{
Association of neutrophil-to-lymphocyte ratio, neutrophil count, and VEGF on metastasis in patients with nasopharyngeal carcinoma
}

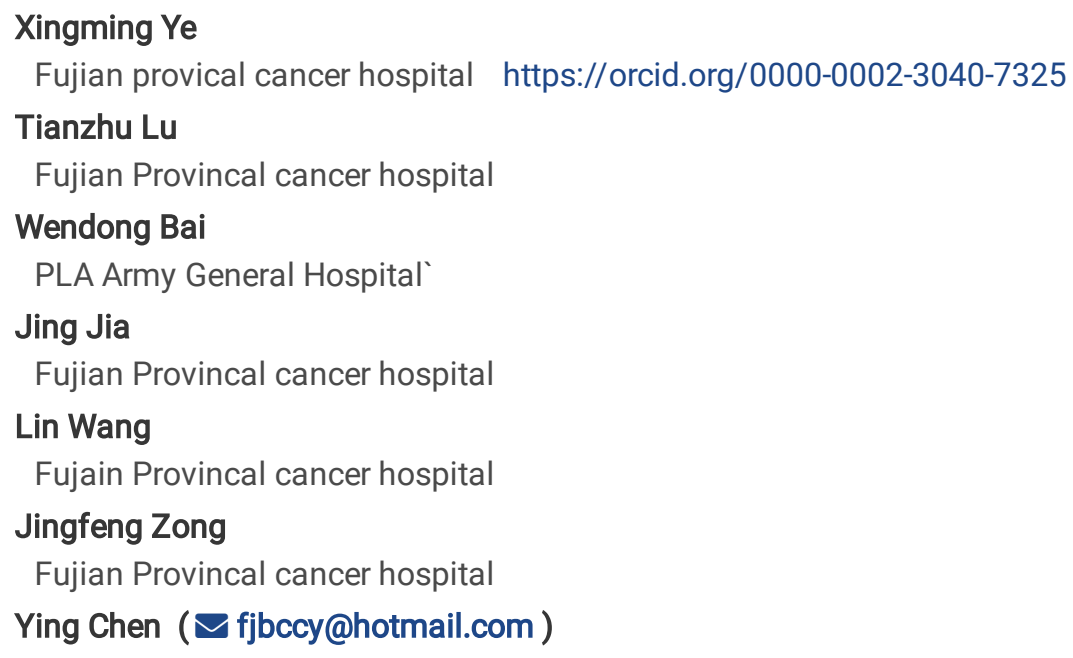

Tianzhu Lu

Fujian Provincal cancer hospital

Wendong Bai

PLA Army General Hospital'

Jing Jia

Fujian Provincal cancer hospital

Lin Wang

Fujain Provincal cancer hospital

Jingfeng Zong

Fujian Provincal cancer hospital

Ying Chen ( $\nabla$ fjbccy@hotmail.com )

\section{Research}

Keywords: NLR, neutrophil count, VEGF, nasopharyngeal carcinoma, metastasis

Posted Date: May 17th, 2020

DOI: https://doi.org/10.21203/rs.3.rs-26726/v1

License: (9) (7) This work is licensed under a Creative Commons Attribution 4.0 International License. Read Full License 


\section{Abstract \\ Background}

Systemic inflammatory responses have important roles in the development and progression of cancer, including the propensity for metastasis. A high neutrophil-to-lymphocyte ratio (NLR) is associated with poor prognosis in nasopharyngeal carcinoma (NPC), but the underlying mechanisms are not clear. Vascular endothelial growth factor (VEGF) has been reported to be involved in the recruitment of pro-angiogenic neutrophils in tumor metastasis progress. Therefore, we focused on the correlations among NLR, neutrophil count, and VEGF during metastasis and explored the reasons for changes of NLR in advanced NPC.

\section{Methods}

Consecutive patients who had been investigated with magnetic resonance imaging and irradiated with intensity-modulated radiotherapy(IMRT) from November 2011 to December 2012 were studied retrospectively. Clinical parameters (NLR, neutrophil count) were measured and their association with NPC stage advancement and VEGF were assessed using the Kruskal-Wallis test. Associations with patient survival were analyzed using the Kaplan-Meier method and log-rank test.

\section{Results}

NLR was elevated in advanced $\mathrm{N}$ stage $(P<0.0001)$ and $\mathrm{M}$ stage disease $(P=0.0034)$, but not T stage disease $(P=0.7049)$. Changes to the NLR in advanced $\mathrm{N}$ stage and $\mathrm{M}$ stage disease were affected most strongly by neutrophil count $(P=0.0074$ and $P=0.0064$, respectively) and higher NLR levels were associated with higher neutrophil count $(P<0.0001)$. NLR $>2.26$ and positive VEGF expression $(+++)$ correlated significantly with distant metastasis-free survival $(P=0.0340$ and $P=0.0023$, respectively). Neutrophil counts correlated positively with VEGF expression $(P=0.0024)$ in NPC tissue.

\section{Conclusion}

Our results demonstrate a positive correlation between NLR, neutrophil count, and VEGF expression in NPC. Higher NLR and VEGF expression are associated with distant metastasis-free survival among patients with NPC, which implies that they set a basis of immune activation in advanced nasopharyngeal carcinoma.

\section{Introduction}

The occurrence of nasopharyngeal carcinoma (NPC) is rare worldwide but has reached epidemic proportions in Southeast Asia. In southern China, the annual incidence of NPC is $15-30$ cases per 100,000 people [1]. The treatment strategy for NPC is mainly based on the tumor-node-metastasis (TNM) staging system. Radiotherapy alone is generally effective for early stage NPC, while chemoradiotherapy remains the standard treatment for patients with advanced disease [2]. However, even after definitive chemoradiotherapy, $15 \%-30 \%$ of patients eventually develop distant metastases (DM), which is the major cause of death among patients with NPC [3, 4].

Previous work has demonstrated that a high neutrophil-to-lymphocyte ratio (NLR) is associated with DM and poor treatment outcomes in patients with NPC [5 - 9], which suggests that NLR may represent an easily measurable and inexpensive prognostic marker in NPC. However, the underlying changes in cell counts that drive NLR alterations remain unclear.

NLR is the ratio of two sub-types of white blood cells: neutrophils and lymphocytes. Recent studies suggest that these inflammatory makers have a critical role in the immune system and the inflammatory response during various stages of carcinogenesis including initiation, invasion, progression, and metastasis [10-12]. Neutrophils initiate interactions between cancer cells and endothelial cells in the vicinity of the primary tumor microenvironment to expedite metastasis via the release of growth factors such as vascular endothelial growth factor (VEGF) and proteases [13]. Lymphocytes act to prevent tumor cell proliferation and migration [14]. However, whether alterations in these cell counts result in elevated NLR during NPC progress is controversial $[15,16]$. Here, we revealed that neutrophils have a crucial function in the metastasis of NPC.

Page 2/12 
VEGF is an important prognostic marker and therapeutic target in NPC [17] and is produced by tumors is known to recruit proangiogenic neutrophils, which are associated with the development of DM $[18,19]$. We hypothesized that there is a link between these clinical variables and the levels of relevant cytokines in NPC progression. In this study, we focused on the relationship between NLR and immune cells in metastatic progress. We also explored the mechanisms underlying changes in NLR in metastatic NPC.

\section{Methods}

\section{Patients}

The study protocol was approved by the ethics committee of Fujian Cancer Hospital, and informed consent was obtained from all patients. We reviewed the records of 834 patients with NPC who were irradiated consecutively with IMRT at our hospital between November 2011 and December 2012. Pretreatment evaluations included complete medical history, physical examination, nasopharyngoscopy examination, dental evaluation, standard laboratory tests, chest radiography or computed tomography, bone scan, and abdominal ultrasound. None of the patients had received any cancer-specific treatment at the time of data collection. Patients with evidence of infection, hematological disease, renal dysfunction, or hyperpyrexia were excluded from the study. A diagnosis of NPC was made via endoscopy-guided biopsy. Disease re-staging was defined according to the criteria of the 8th edition of the American Joint Committee on Cancer staging system.

\section{Tissue Samples And Laboratory Tests}

VEGF expression were measured in 834 patients. Tumor samples were collected from a total of 62 patients, then immediately frozen in liquid nitrogen and stored at $-80^{\circ} \mathrm{C}$, followed by immunohistochemical staining with rabbit anti-human VEGF (1:100; Abcam Inc., Cambridge, MA, USA). VEGF expression was described as ' + ', ' ++ ', or ' +++ ' to denote weak, moderate, or strong positive staining, respectively. Thirty percent of all positive cells were weakly positive (+), 30-71\% were moderately positive (++), and $29 \%$ were strongly positive (+++) [20].

Laboratory data, including total white blood cell (WBC), neutrophil, lymphocyte and platelet counts, NLR and PLR ratios (based on counts per $\mu \mathrm{L}$ of whole blood), hemoglobin ( $\mathrm{Hb}$ ) level, and red cell width distribution (RDW) were measured as part of the automated complete blood count on a Sysmex XE-2100 analyzer (Sysmex Corporation, Japan).

\section{Statistical analysis}

Receiver operating characteristic (ROC) curves were constructed to select cut-off values for the stratification of patients based on pretreatment laboratory parameters. Data are expressed as the median and interquartile range (IQR) or mean and $95 \%$ confidence interval $(\mathrm{Cl})$, as appropriate. Laboratory parameters in patient and control groups were compared with Student's $t$-tests for variables with normal distribution or with the Mann-Whitney U-test for abnormally distributed variables. All DM-free survival curves were analyzed only for M0 stage patients and constructed using the Kaplan-Meier method, then analyzed with the log-rank test and multivariate Cox-regression analysis. The associations between laboratory parameters and tumor stage were assessed using the Kruskal-Wallis test. Univariate logistic regression was used as a statistical model to show the probability of NLR versus neutrophil counts values. Statistical significance was defined as $P<0.05$ (two-tailed). All analyses were performed using Prism 5 (GraphPad Software, La Jolla, CA, USA) and SPSS version 17 (SPSS, Chicago, IL, USA) software.

\section{Results}

\section{NLR predicts outcome in NPC patients with distant metastasis}

Table 1 depicts the basic characteristics of all patients included in the study. To assess the association with DM-free survival, we categorized the M0 stage NPC patients (785) into groups using NLR, PLR, and WBC cut-off values of 2.26, 87.6, and 6.9, respectively, based on the results of ROC curve analyses (data not shown). Patients with high baseline NLR $(\geq 2.26)$ had worse DM-free survival than patients with low baseline NLR (<2.26; $P=0.034$, HR: 1.5, 95\% Cl: 1.1-1.9; Fig. 1A). However, no significant association between DM-free survival and PLR or WBC was detected (Fig. 1B and C). 
Table 1

Clinicopathological characteristics of

NPC patients

\begin{tabular}{|ll|}
\hline Characteristic & No. of Patients (\%) \\
\hline Gender & \\
\hline Male & $612(73.4)$ \\
\hline Female & $222(26.6)$ \\
\hline Age(yrs) & \\
\hline S 50 & $491(58.9)$ \\
\hline$>50$ & $343(41.1)$ \\
\hline T category & \\
\hline T1 & $119(14.3)$ \\
\hline T2 & $181(21.7)$ \\
\hline T3 & $272(32.6)$ \\
\hline T4 & $262(31.4)$ \\
\hline N category & \\
\hline N0 & $6(0.7)$ \\
\hline N1 & $179(21.5)$ \\
\hline N2 & $463(55.5)$ \\
\hline N3 & $186(22.3)$ \\
\hline M category & \\
\hline M0 & $785(94.1)$ \\
\hline M1 & $49(5.9)$ \\
\hline Clinical stages & \\
\hline Stage I & $7(0.8)$ \\
\hline Stage II & $49(5.9)$ \\
\hline Stage III & $411(49.3)$ \\
\hline Stage IV & $367(44.0)$ \\
\hline
\end{tabular}

NLR and neutrophil count changes are associated with advanced $\mathrm{N}$ and $\mathrm{M}$ stage Next, we examined changes in clinical parameters in NPC patients stratified according to TNM stage (Table 2 and Fig. 2). Kruskal-Wallis analysis revealed that NLR and neutrophil counts were significantly associated with increasing $\mathrm{N}$ stage $(P<0.0001$ and $P=0.0074$, respectively) and significantly higher in the M1 compared with the M0 subgroup ( $P=0.0034$ and $P=0.0064$, respectively; Fig. $2 \mathrm{~A}$ and $\mathrm{B}$ ). Both had no significant association with $\mathrm{T}$ stage ( $P=0.7049$ and $P=0.2133$, respectively; Table 2$)$. 
Table 2

Association between hematologic markers TNM stage in NPC

\begin{tabular}{|c|c|c|c|c|c|c|c|c|c|c|}
\hline & NLR & $\begin{array}{l}P \\
\text { value }\end{array}$ & PLR & $\begin{array}{l}P \\
\text { value }\end{array}$ & $\begin{array}{l}\text { Lymphocyte } \\
\left(10^{9} / \mathrm{L}\right)\end{array}$ & $\begin{array}{l}P \\
\text { value }\end{array}$ & $\begin{array}{l}\text { Neutrophil } \\
\left(10^{9} / \mathrm{L}\right)\end{array}$ & $\begin{array}{l}P \\
\text { value }\end{array}$ & $\begin{array}{l}\text { Platelet } \\
\left(10^{9} / \mathrm{L}\right)\end{array}$ & $\begin{array}{l}P \\
\text { value }\end{array}$ \\
\hline \multicolumn{11}{|c|}{$\begin{array}{l}\text { T } \\
\text { category }\end{array}$} \\
\hline $\mathrm{T} 1$ & $\begin{array}{l}2.2(0.7 \\
-7.7)\end{array}$ & & $\begin{array}{l}123.9(52.7 \\
-249.8)\end{array}$ & & $\begin{array}{l}1.9(0.9- \\
4.5)\end{array}$ & & $\begin{array}{l}4.1(1.8- \\
10.7)\end{array}$ & & $\begin{array}{l}236.5(109.0 \\
-393.0\end{array}$ & \\
\hline $\mathrm{T} 2$ & $\begin{array}{l}2.1(0.8 \\
-13.4)\end{array}$ & 0.7049 & $\begin{array}{l}122.9(52.8 \\
-504.6)\end{array}$ & 0.2844 & $\begin{array}{l}1.9(0.4- \\
3.8)\end{array}$ & 0.7513 & $\begin{array}{l}4.0(1.9- \\
10.9)\end{array}$ & 0.2133 & $\begin{array}{l}239.0(127.0 \\
-433.0\end{array}$ & 0.0012 \\
\hline T3 & $\begin{array}{l}2.1(0.7 \\
-12.4)\end{array}$ & & $\begin{array}{l}118.3(41.8 \\
-353.9)\end{array}$ & & $\begin{array}{l}2.0(0.7- \\
5.4)\end{array}$ & & $\begin{array}{l}4.0(1.5- \\
13.0)\end{array}$ & & $\begin{array}{l}230.5(103.0 \\
-447.0\end{array}$ & \\
\hline $\mathrm{T} 4$ & $\begin{array}{l}2.1(0.7 \\
-9.4)\end{array}$ & & $\begin{array}{l}124.6(50.9 \\
-370.8)\end{array}$ & & $\begin{array}{l}1.9(0.6- \\
4.5)\end{array}$ & & $\begin{array}{l}4.2(1.4- \\
11.3)\end{array}$ & & $\begin{array}{l}243.0(124.0 \\
-483.0\end{array}$ & \\
\hline \multicolumn{11}{|c|}{$\begin{array}{l}\mathrm{N} \\
\text { category }\end{array}$} \\
\hline NO & $\begin{array}{l}2.0(0.8 \\
-6.5)\end{array}$ & & $\begin{array}{l}110.1(52.1 \\
-357.9)\end{array}$ & & $\begin{array}{l}2.0(0.7- \\
3.0)\end{array}$ & & $\begin{array}{l}3.9(1.6- \\
8.8)\end{array}$ & & $\begin{array}{l}220.5(109.0 \\
-345.0\end{array}$ & \\
\hline $\mathrm{N} 1$ & $\begin{array}{l}2.0(0.7 \\
-12.4)\end{array}$ & $\begin{array}{l}< \\
0.0001\end{array}$ & $\begin{array}{l}121.9(52.7 \\
-504.6)\end{array}$ & 0.0024 & $\begin{array}{l}2.0(0.6- \\
4.5)\end{array}$ & 0.1653 & $\begin{array}{l}4.0(1.5- \\
13.0)\end{array}$ & 0.0032 & $\begin{array}{l}236.5(109.0 \\
-483.0)\end{array}$ & 0.0164 \\
\hline N2 & $\begin{array}{l}2.1(0.7 \\
-13.4)\end{array}$ & & $\begin{array}{l}121.2(41.8 \\
-435.2)\end{array}$ & & $\begin{array}{l}1.9(0.4- \\
3.9)\end{array}$ & & $\begin{array}{l}4.0(1.4- \\
11.3)\end{array}$ & & $\begin{array}{l}237.0(103.0 \\
-475.0)\end{array}$ & \\
\hline N3 & $\begin{array}{l}2.7(0.8 \\
-7.7)\end{array}$ & & $\begin{array}{l}136.1(51.0 \\
-439.0)\end{array}$ & & $\begin{array}{l}1.8(0.6- \\
5.4)\end{array}$ & & $\begin{array}{l}4.6(2.1- \\
10.7)\end{array}$ & & $\begin{array}{l}250.0(124.0 \\
-434.0)\end{array}$ & \\
\hline \multicolumn{11}{|c|}{$\begin{array}{l}\text { M } \\
\text { category }\end{array}$} \\
\hline MO & $\begin{array}{l}2.1(0.7 \\
-13.0)\end{array}$ & 0.0034 & $\begin{array}{l}122.5(41.8 \\
-504.6)\end{array}$ & 0.3038 & $\begin{array}{l}1.9(0.4- \\
5.4)\end{array}$ & 0.6609 & $\begin{array}{l}4.0(1.4- \\
13.0)\end{array}$ & 0.0064 & $\begin{array}{l}237.0(103.0 \\
-483.0)\end{array}$ & 0.0782 \\
\hline M1 & $\begin{array}{l}2.4(1.1 \\
-9.0)\end{array}$ & & $\begin{array}{l}123.9(60.9 \\
-359.8)\end{array}$ & & $\begin{array}{l}2.0(0.9- \\
3.8)\end{array}$ & & $\begin{array}{l}4.7(2.4- \\
9.5)\end{array}$ & & $\begin{array}{l}251.0(158.0 \\
-475.0)\end{array}$ & \\
\hline
\end{tabular}

\section{Correlation Between NLR, Neutrophil Count Levels, And Metastasis}

Univariate logistic regression showed the baseline NLR levels were significantly associated with neutrophil count $(P<0.0001)$ (Fig. 3A and B), but not lymphocyte count (Table 2). In other words, higher NLR was associated with higher neutrophil counts. Furthermore, N3 stage patients (Fig. 3A) and DM patients (Fig. 3B) in NPC showed a positive correlation with elevated NLR, which was dominated by neutrophil counts.

\section{Neutrophil count is positively associated with tumor VEGF expression in NPC patients}

Figure 4A shows that DM-free survival worsened significantly if VEGF expression was strongly positive (+++; $P=0.0023, \mathrm{HR}: 3.66$, 95\%Cl: 1.82-15.79). Kruskal-Wallis analysis revealed that neutrophil count was significantly associated with VEGF expression ( $P=$ 0.0024 , Fig. 4B), which suggests that tumor VEGF production may contribute to the increase in neutrophil count.

\section{Discussion}

Elevated NLR has previously been reported to be a risk factor for DM and an indicator of poor prognosis in NPC patients [5-9], although the reasons for this are obscure. In this retrospective study, we found that increases in NLR and neutrophil count were significantly associated with lymph node involvement and DM. For the first time, we found that in the process of NPC metastasis, changes in NLR were driven by an increase in neutrophil count, which correlated significantly with VEGF expression. 
Among the parameters examined here, NLR and PLR showed an association with advanced lymph node involvement (N3) (Fig. 2A and Table 2), but only NLR was significantly associated with DM and DM-free survival. This finding is consistent with others reported in similar studies of head and neck cancer, which showed that PLR was not significantly associated with survival [21 - 23]. However, increasing evidence suggests that PLR is a useful prognostic factor for lung and colon cancer [24, 25]. This apparent discrepancy may be caused by tumor heterogeneity, among other factors. Taken together, our results implicate a neutrophil-dependent inflammatory response in the development of NPC metastasis.

Neutrophils actively participate in various steps of the metastatic cascade [26 - 29]. Our finding here that neutrophil counts increase with advancing NPC is consistent with previous studies showing that myeloid cells facilitate tumor advancement by promoting an inflammatory tumor microenvironment, which is required for epithelial-mesenchymal transition, intravasation, and tumor metastasis [30]. The previously published finding that neutrophils release growth factors such as VEGF and specific proteases [31, 32] supports our finding that VEGF expression was positively associated with neutrophil count in NPC tissue.

We found that NPC patients had significantly lower lymphocyte counts than healthy controls (Table 3); however, there was no obvious association of lymphocyte count with either advancing disease stage or the development of metastasis (Table 2). Lymphocytes play an essential role in the anti-tumor immune response, impeding tumor cell proliferation and migration and inducing cell death [33]. Thus, although lymphocytes affect tumor growth, they likely have little influence on metastasis in NPC.

Table 3

\begin{tabular}{|llll|}
\hline & controls & NPC patients & Pvalue \\
\hline WBC $\left(10^{9} / \mathrm{L}\right)$ & $6.3(2.4-15.3)$ & $6.8(3.3-14.9)$ & $<0.0001$ \\
\hline Neutrophil $\left(10^{9} / \mathrm{L}\right)$ & $3.4(1.2-11.7)$ & $4.0(1.41-13.03)$ & $<0.0001$ \\
\hline Lymphocyte $\left(10^{9} / \mathrm{L}\right)$ & $2.1(0.7-4.9)$ & $1.9(0.42-5.36)$ & $<0.0001$ \\
\hline Platelet $\left(10^{9} / \mathrm{L}\right)$ & $223(35-401)$ & $238(103-483)$ & $<0.0001$ \\
\hline $\mathrm{Hb}(\mathrm{g} / \mathrm{L})$ & $143(90-175)$ & $141(79-176)$ & 0.0178 \\
\hline $\mathrm{RDW}(\%)$ & $13.1(10.9-19.4)$ & $12.9(10.4-19.9)$ & $<0.0001$ \\
\hline $\mathrm{NLR}$ & $1.61(0.58-7.46)$ & $2.12(0.65-9.36)$ & $<0.0001$ \\
\hline PLR & $105.2(40.4-253)$ & $122.79(41.81-504.63)$ & $<0.0001$ \\
\hline Comparison of laboratory parameters in NPC patients and healthy control subjects \\
\hline
\end{tabular}

VEGF is a tumor-produced growth factor that contributes to tumor angiogenesis and metastasis [34 - 38], and high VEGF expression has previously been associated with poor prognosis in patients with NPC [39]. The significant correlation between VEGF and neutrophil count demonstrated here may provide the immunological basis for the clinical observation that a very high NLR is correlated with poor survival [5 - 9]. The association identified in the present study suggests that these parameters could be markers for the precise curative effect of the anti-VEGF monoclonal antibody bevacizumab, which is currently used to treat NPC [40].

There are several limitations to this study. First, it was retrospective. Second, the number of patients with stage I/II NPC was low (7 and 49 patients, respectively), which may have reduced the statistical power for the subgroup analysis. Thus, our observations must be validated in a large-scale prospective study. Moreover, further work is required to detect the mechanism for increased NLR in NPC metastasis.

\section{Conclusions}

These findings indicate that there is a close interaction between NLR, neutrophil count, and VEGF in NPC-related metastasis. Among all the factors investigated in this study, a stage-dependent increase in neutrophil count, which correlated positively with tumor VEGF expression, contributed most strongly to changes in NLR in the progression of locally advanced and metastatic NPC.

\section{Abbreviations}


AJCC

American Joint Committee on Cancer

DMFS

distant metastasis-free survival

NLR

neutrophil-to-lymphocyte ratio

NPC

nasopharyngeal carcinoma

ROC

receiver operating characteristic

TNM

tumor-node metastasis

\section{Declarations}

\section{Acknowledgements}

Not applicable.

\section{Funding}

This research was supported by the Fujian Provincial Health Commission Youth Backbone Program (No.2016-ZQN-15), Joint Funds for the Innovation of Science and Technology, Fujian Province (No.2018Y9114), and the National Natural Sciences Foundation of China (No. 81802661 and 81972717 ).

\section{Availability of supporting data}

All data generated of analyzed during this study are included in this published article.

\section{Authors' contributions}

XMY, TZL, and WDB acquired and analyzed the data. JJ and LW analyzed the data. YC conceived and designed the study. JFZ wrote the manuscript. All authors read and approved the final manuscript.

\section{Ethical approval and consent to participate}

This study was conducted in compliance with institutional policy to protect patients' private information and was approved by the Institutional Review Board of Fujian Cancer Hospital(No.200908).

\section{Consent for publication}

Not applicable.

\section{Competing interests}

The authors declare no competing financial interests.

\section{References}

1. Cao SM, Simons MJ, Qian CN. The prevalence and prevention of nasopharyngeal carcinoma in China. Chin J Cancer. 2011;30(2):114-9.

2. Chan AT, Chan AT, Grégoire V, Lefebvre JL, Licitra L, Felip E. Nasopharyngeal cancer: EHNS - ESMO - ESTRO Clinical Practice Guidelines for diagnosis, treatment and follow - up. Ann Oncol. 2010;21(Suppl 5):v187 - v189.

3. Lee AW, Ng WT, Chan LL, Hung WM, Chan CC, Sze HC, Chan OS, Chang AT, Yeung RM. Evolution of treatment for nasopharyngeal cancer - success and setback in the intensity - modulated radiotherapy era. Radiother Oncol. 2014;110:377-84. 
4. Lai SZ, Li WF, Chen L, Luo W, Chen YY, Liu LZ, Sun Y, Lin AH, Liu MZ, Ma J. How does intensity - modulated radiotherapy versus conventional two - dimensional radiotherapy influence the treatment results in nasopharyngeal carcinoma patients? Int $\mathrm{J}$ Radiat Oncol Biol Phys. 2011;80, $661-668$.

5. An X, Ding PR, Wang FH, Jiang WQ, Li YH. Elevated neutrophil to lymphocyte ratio predicts poor prognosis in nasopharyngeal carcinoma. Tumor Biol. 2011;32(2):317-24.

6. Sun W, Zhang L, Luo M, Hu G, Mei Q, Liu D, Long G, Hu G. Pretreatment hematologic markers as prognostic factors in patients with nasopharyngeal carcinoma: neutrophil - lymphocyte ratio and platelet - lymphocyte ratio. Head Neck. 2016;38(Suppl1):E133240.

7. Chua ML, Tan SH, Kusumawidjaja G, Shwe MT, Cheah SL, Fong KW, Soong YL, Wee JT, Tan TW. Neutrophil - to - lymphocyte ratio as a prognostic marker in locally advanced nasopharyngeal carcinoma: a pooled analysis of two randomised controlled trials. Eur J Cancer. 2016;67:119-29.

8. Yin J, Qin Y, Luo YK, Feng M, Lang JY. Prognostic value of neutrophil - to lymphocyte ratio for nasopharyngeal carcinoma: a meta - analysis. Medicine(Baltimore). 2017;96(29):e7577.

9. Yao J, Zhu F, Dong J, Liang Z, Yang L, Chen S, Zhang W, Lawrence WR, Zhang F, Wang S, Sun Y, Zhou G. Prognostic value of neutrophil - to - lymphocyte ratio in advanced nasopharyngeal carcinoma: a large institution - based cohort study from an endemic area. BMC Cancer. 2019;19:37-45.

10. Chang SH, Mirabolfathinejad SG, Katta H, Cumpian AM, Gong L, Caetano MS, Moghaddam SJ, Dong C. T helper 17 cells play a critical pathogenic role in lung cancer. Proc Natl Acad Sci. 2014;111:5664-9.

11. Gong L, Cumpian AM, Caetano MS, Ochoa CE, De la Garza MM, Lapid DJ, Mirabolfathinejad SG, Dickey BF, Moghaddam SJ. Promoting effect of neutrophils on lung tumorigenesis is mediated by CXCR2 and neutrophil elastase. Mol Cancer. 2013;12:154.

12. Houghton AM. Rzymkiewicz DM, Ji H, Gregory AD, Egea EE, Metz HE, Stolz DB, Land SR, Marconcini LA, Kliment CR, Jenkins KM, Beaulieu KA, Meuded M, Frank SJ, Wong KK, Shaprio SD. Neutrophil elastase-mediated degradation of IRS-1 accelerates lung tumor growth. Nat Med. 2010;16:219-23.

13. Christoffersson G, Vågesjö E, Vandooren J, Lidén M, Massena S, Reinert RB, Brissova M, Powers AC, Opdenakker G, Phillipson M. VEGF - A recruits a proangiogenic MMP - 9-delivering neutrophil subset that induces angiogenesis in transplanted hypoxic tissue. Blood. 2012;120(23):4653-62.

14. Zhao J, Huang W, Wu Y, Luo Y, Wu B, Cheng J, Chen J, Liu D, Li C. Prognostic role of pretreatment blood lymphocyte count in patients with solid tumors:a systematic review and meta-analysis. Cancer cell Int. 2020;20:15.

15. Su L, Zhang MZ, Zhang WJ, Cai CS, Hong JS. Pretreatment hematologic markers as prognostic factor in patients with nasopharyngeal canrcinoma a systematic review and meta-analysis. Medicine. 2017;96:11(e6364).

16. Yin J, Qin Yuan, Luo YK, Feng M, Lang JJ. Prognostic value of neutrophil-to- lymphocyte ratio for nasopharyngeal carcinoma a meta-analysis. Medicine. 2017;96:29(e7577).

17. Cheng JZ, Chen JJ, Xue K, Wang ZG, Yu D. Clinicopathologic and prognostic signifcance of VEGF, JAK2 and STAT3 in patients with nasopharyngeal carcinoma. Cancer cell Int. 2018;18:110-9.

18. Christoffersson G, Vågesjö E, Vandooren J, Lidén M, Massena S, Reinert RB, Brissova M, Powers AC, Opdenakker G, Phillipson M. VEGF - A recruits a proangiogenic MMP - 9-delivering neutrophil subset that induces angiogenesis in transplanted hypoxic tissue. Blood. 2012;120(23):4653-62.

19. Segawa Y, Oda Y, Yamamoto H, Shiratsuchi H, Hirakawa N, Komune S, Iwamoto Y, Oda Y. Close correlation between CXCR4 and VEGF expression and their prognostic implications in nasopharyngeal carcinoma. Oncol Rep. 2009;21:1197-202.

20. Volm M, Koomagi R, Mattern J. Prognostic value of vascular endothelial growth factor and its receptor Flt-1 in squamous cell lung cancer. Int J Cancer. 1997;74:64-8.

21. Young CA, Murray LJ, Karakaya E, Thygesen HH, Sen M, Prestwich RJ. The prognostic role of the neutrophil - to - lymphocyte ratio in oropharyngeal carcinoma treated with chemoradiotherapy. Clin Med Insights Oncol. 2014;8:81-6.

22. Farhan - Alanie OM, McMahon J, McMillan DC. Systemic inflammatory response and survival in patients undergoing curative resection of oral squamous cell carcinoma. Br J Oral Maxillofac Surg. 2015;53:126-31.

23. Selzer E, Grah A, Heiduschka G, Kornek G, Thurnher D. Primary radiotherapy or postoperative radiotherapy in patients with head and neck cancer: Comparative analysis of inflammation - based prognostic scoring systems. Strahlenther Onkol. 2015;191:48694. 
24. Ding N, Pang ZF, Shen H, Ni Y, Du J, Liu Q. The prognostic value of PLR in lung cancer, a Meta - analysis Based on Results from a Large Consecutive Cohort. Sci Rep. 2016;6:34823.

25. Liu Y, Chen Y, Chen S, Li Z, Zhao X, Zhang W, Zhi F. Platelet to lymphocyte ratio might be a prognostic factor of colorectal cancer (CRC): A meta - analysis. Int J Clin Exp Med. 2016;9:11090-5.

26. Welch DR, Schissel DJ, Howrey RP, Aeed PA. Tumor-elicited polymorphonuclear cells, in contrast to "normal" circulating polymorphonuclear cells, stimulate invasive and metastatic potentials of rat mammary adenocarcinoma cells. Proc Natl Acad Sci. 1989;86:5859-63.

27. Huh SJ, Liang S, Sharma A, Dong C, Robertson GP. Transiently entrapped circulating tumor cells interact with neutrophils to facilitate lung metastasis development. Cancer Res. 2010;70:6071-82.

28. Spicer JD, McDonald B, Cools-Lartigue JJ, Chow SC, Giannias B, Kubes P, Ferri LE, Nowarski R, Thaiss CA, Hu B, Jin C, Flavell RA. Neutrophils promote liver metastasis via Mac-1-mediated interactions with circulating tumor cells. Cancer Res. 2012;72:3919-27.

29. Cools-Lartigue J, Spicer J, McDonald B, Chow S, Giannias B, Bourdeau F, Kubes P, Ferri LE. Neutrophil extracellular traps sequester circulating tumor cells and promote metastasis. J Clin Invest. 2013;123:3446-58.

30. Elinav E, Nowarski R, Thaiss CA, Hu B, Jin C, Flavell RA. Inflammation - induced cancer: crosstalk between tumors, immune cells and microorganisms. Nat Rev Cancer. 2013;13:759-71.

31. Paramanathan A, Saxena A, Morris DL. A systematic review and meta - analysis on the impact of pre - operative neutrophil lymphocyte ratio on long term outcomes after curative intent resection of solid tumors. Surg Oncol. 2014;23(1):31-9.

32. Kusumanto YH, Dam WA, Hospers GA, Meijer C, Mulder NH. Platelets and granulocytes, in particular the neutrophils, form important compartments for circulating vascular endothelial growth factor. Angiogenesis. 2003;6(4):283-7.

33. Swann JB, Smyth MJ. Immune surveillance of tumors. J Clin Invest. 2007;117(5):1137-46.

34. Fujita K, Sano D, Kimura M, Yamashita Y, Kawakami M, Ishiguro Y, Nishimura G, Matsuda H, Tsukuda M. Anti-tumour effects of bevacizumab in combination with paclitaxel on head and neck squamous cell carcinoma. Oncol Rep. 2007;18:47-51.

35. Vaklavas C, Lenihan D, Kurzrock R, Tsimberidou AM. Anti - vascular endothelial growth factor therapies and cardiovas - cular toxicity: What are the important clinical markers to target? Oncologist. 2010;15:130-41.

36. Li Y, Lu J, Zhou S, Wang W, Tan G, Zhang Z, Dong Z, Kang T, Tang F. Clusterin induced by N,N'-Dinitrosopiperazine is involved in nasopharyngeal carcinoma metastasis. Oncotarget. 2016;7:5548-63.

37. Chen HH, Weng BQ, Cheng KJ, Liu HY, Wang SQ, Lu YY. Effect of the vascular endothelial growth factor expression level on angiopoietin - 2-mediated nasopharyngeal carcinoma growth. Vasc Cell. 2014;6:4.

38. Grunstein J, Roberts WG, Mathieu-Costello O, Hanahan D, Johnson RS. Tumor - derived expression of vascular endothelial growth factor is a critical factor in tumour expansion and vascular function. Cancer Res. 1999;59:1592-8.

39. Li YH, Hu CF, Shao Q, Huang MY, Hou JH, Xie D, Zeng YX, Shao JY. Elevated expressions of survivin and VEGF protein are strong independent predictors of survival in advanced nasopharyngeal carcinoma. J Transl Med. 2008;6:1.

40. Lee NY, Zhang Q, Pfister DG, Kim J, Garden AS, Mechalakos J, Hu K, Le QT, Colevas AD, Glisson BS, Chan AT, Ang KK. Addition of bevacizumab to standard chemoradiation for locoregionally advanced nasopharyngeal carcinoma (RTOG 0615): a phase 2 multi - institutional trial. Lancet Oncol. 2012;13(2):172-80.

\section{Figures}


A

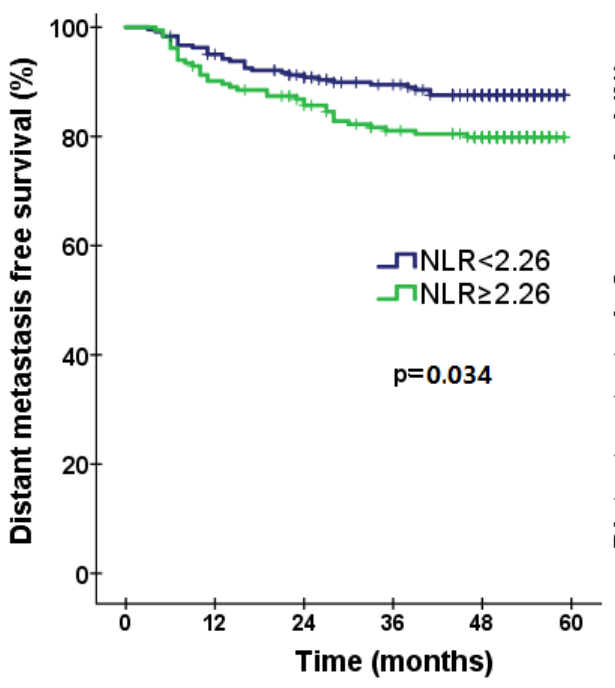

B

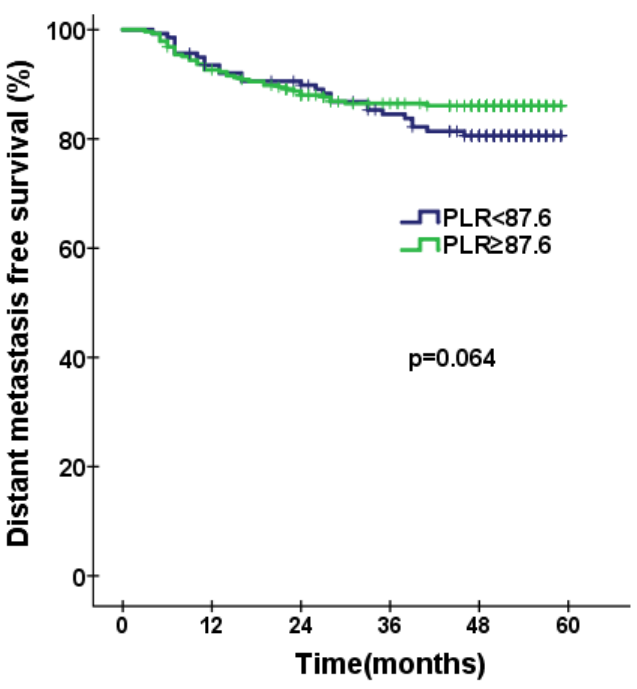

C

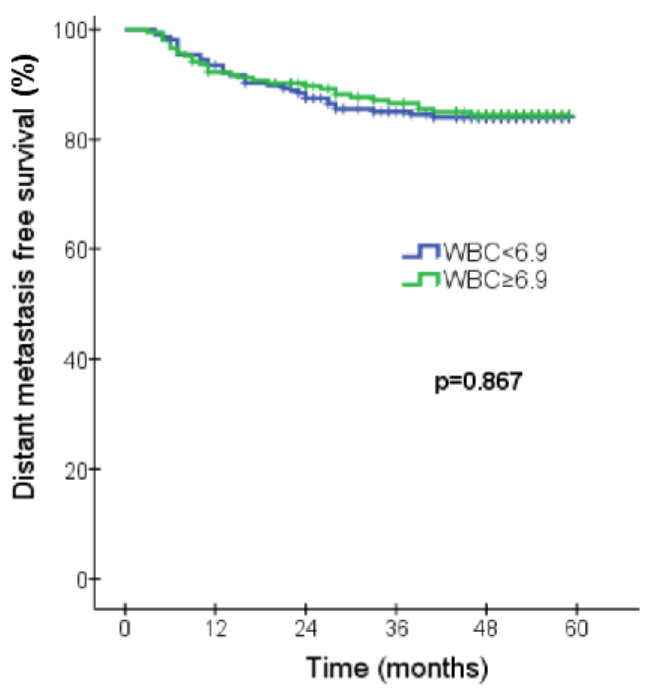

Figure 1

Kaplan-Meier distant metastasis-free survival curves for NPC patients stratified by hematological parameters. Patients were assigned to two groups based on cut-off values for (a) NLR, (b) PLR, and (c) WBC, as determined by ROC curve analysis. The cut-off values were: (a) $\geq 2.26$ and $<2.26$, (b) $\geq 87.6$ and $<87.6$, and (c) $\geq 6.9$ and $<6.9$. 

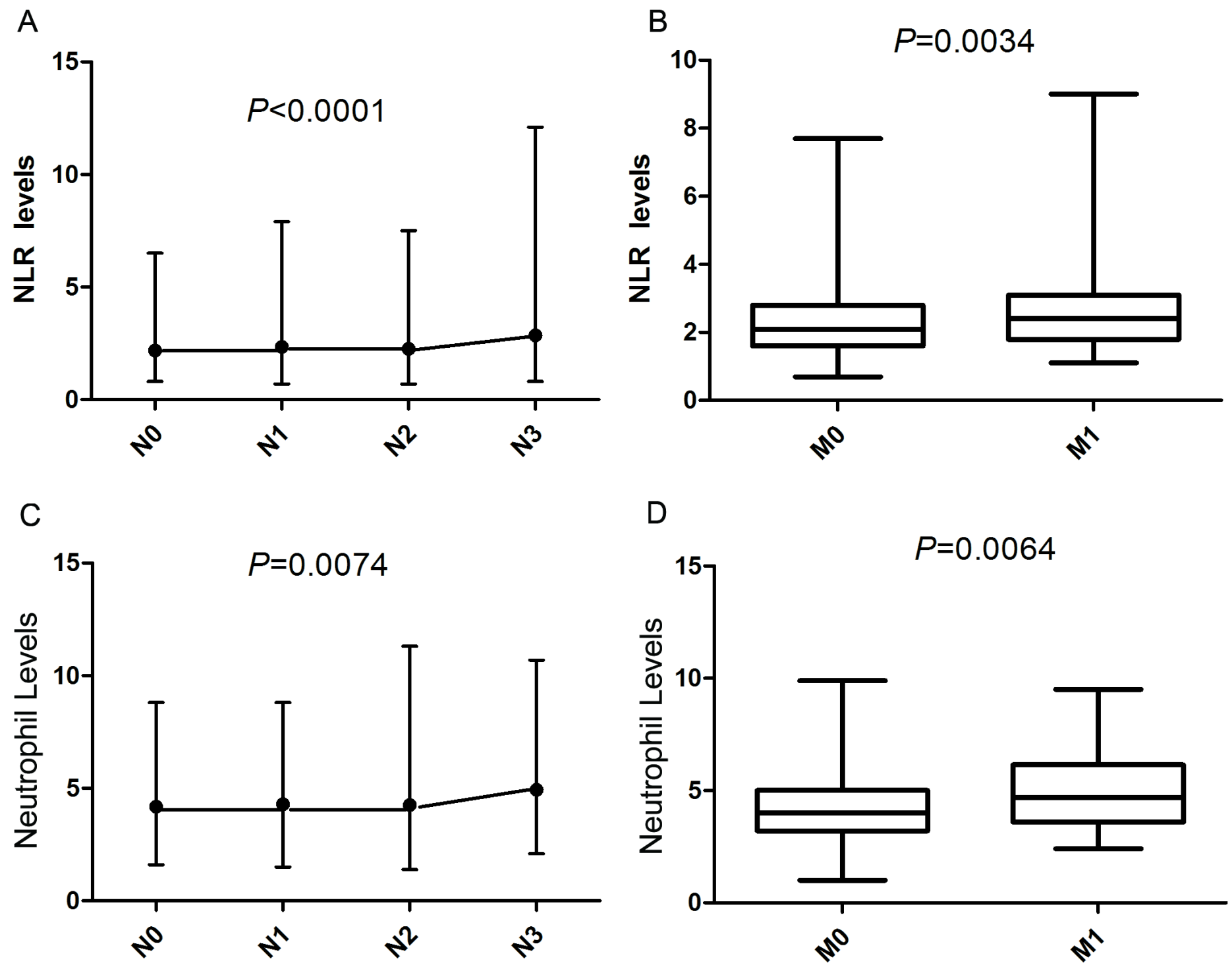

Figure 2

Correlation between NLR and neutrophil in lymph node involvement and distant metastasis. (a) and (b) NLR was elevated in patients with $\mathrm{N}$ or $\mathrm{M}$ stage disease $(\mathrm{P}<0.0001$ and $\mathrm{P}=0.0034$, respectively). (c) and (d) Neutrophil counts in patients with $\mathrm{N}$ or $\mathrm{M}$ stage disease ( $P=0.0074$ and $P=0.0064$, respectively).

A

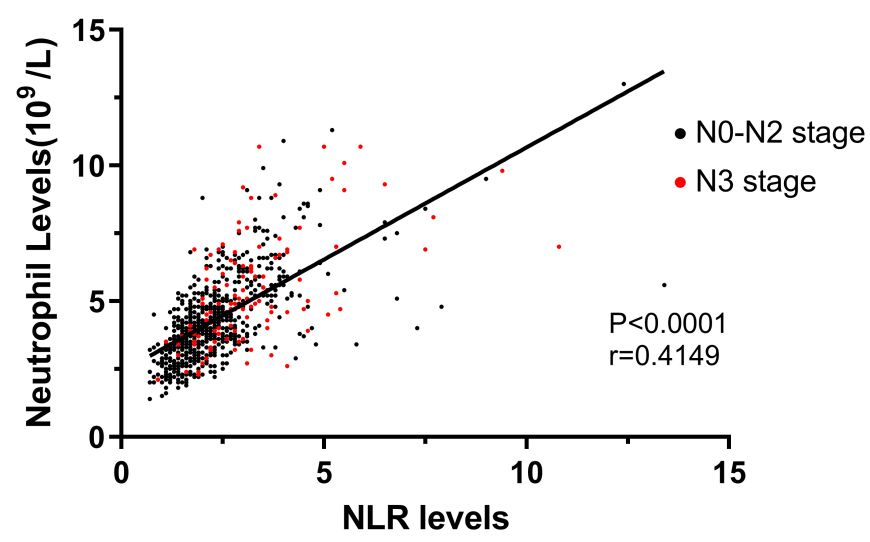

B

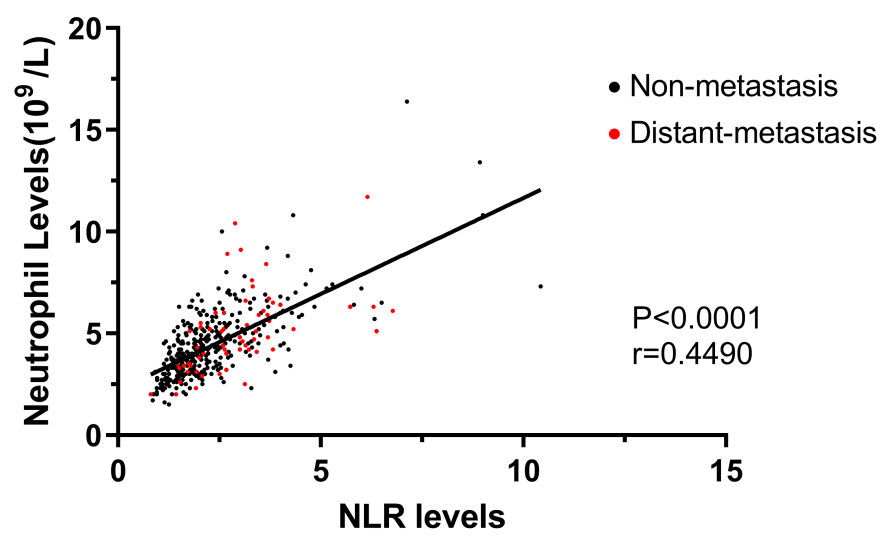




\section{Figure 3}

Correlation between NLR, neutrophil and metastasis. (a) and (b) Linear regression analysis of NLR level and neutrophil count showed higher NLR levels were associated higher neutrophil count $(\mathrm{P}<0.0001)$. (a) Scatter plot depicting the distribution of N3 stage among the NPC patients. (b) Scatter plot depicting the distribution of distant metastasis among the NPC patients.

A

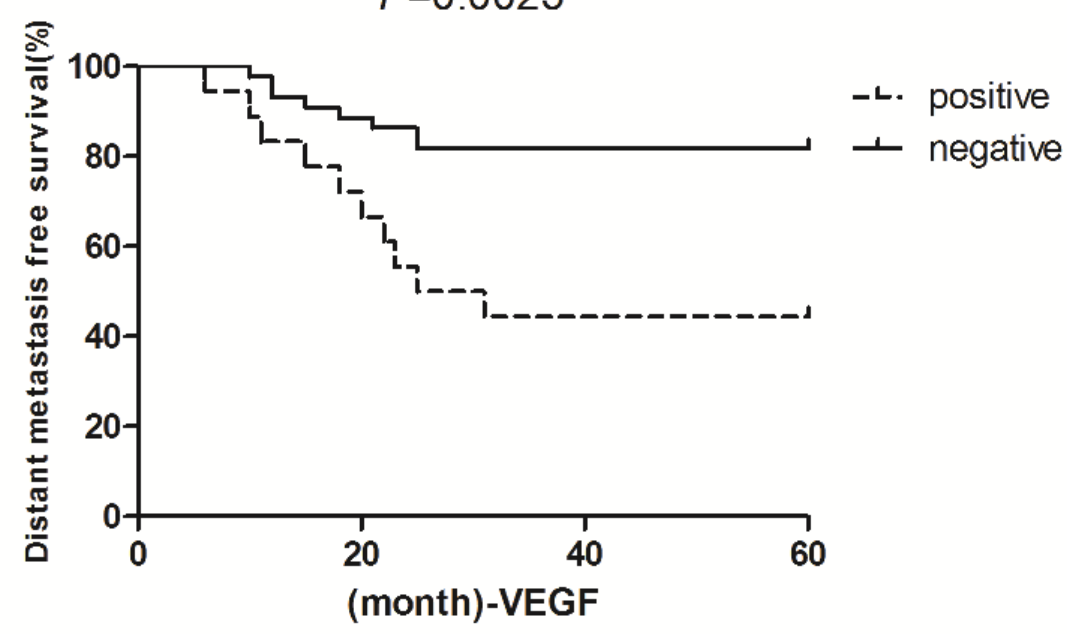

B

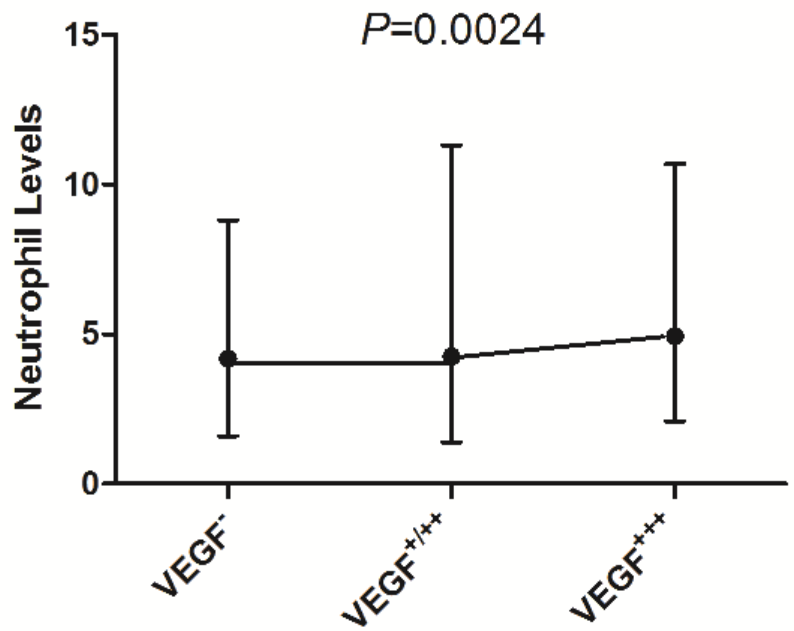

\section{Figure 4}

(a) Kaplan-Meier survival curves for NPC patients with negative and positive expression of VEGF. (b) Neutrophil count in NPC patients with negative, weak/moderate, or strongly positive VEGF expression. 